\title{
Calcium balance in sea bream (Sparus aurata): the effect of oestradiol-17 $\beta$
}

\author{
P M Guerreiro, J Fuentes, A V M Canario and D M Power \\ Centre of Marine Sciences, University of Algarve, 8000-810 Faro, Portugal \\ (Requests for offprints should be addressed to J Fuentes, Centro de Ciências do Mar (CCMar), Universidade do Algarve, Campus de Gambelas, \\ 8000-810 Faro, Portugal; Email: jfuentes@ualg.pt) \\ (P M Guerreiro and J Fuentes contributed equally to this work)
}

\begin{abstract}
In all teleost fishes vitellogenesis is triggered and maintained by oestradiol-17 $\beta\left(\mathrm{E}_{2}\right)$ and is accompanied by an increase of blood plasma calcium and phosphate. The action of this hormone on calcium metabolism was investigated by treating fast-growing immature juvenile sea bream (Sparus aurata) with coconut butter implants alone (control) or implants containing $10 \mu \mathrm{g} / \mathrm{g} \mathrm{E}_{2}$. Treatment with $\mathrm{E}_{2}$ induced the production of circulating vitellogenin, a $2 \cdot 5$-fold increase in plasma ionic $\mathrm{Ca}^{2+}$ and a 10 -fold increase in plasma total calcium, largely bound to protein. In contrast to freshwater species, which obtain most of their calcium from the environment directly through the gills, the intestinal component of calcium uptake of the salt water-living sea bream represented up to $60-70 \%$ of the total uptake. The whole body calcium uptake, expressed as the sum of calcium obtained via intestinal and
\end{abstract}

extra-intestinal (likely branchial) routes increased significantly in response to $\mathrm{E}_{2}$. Combined influx and unchanged efflux rates resulted in a significant 31\% increase in net calcium uptake. There was no evidence for an effect of $E_{2}$ on the calcium and phosphate content of the scales or the tartrate-resistant acid phosphatase activity (an index for bone/scale osteoclast activity). While most freshwater fish appear to rely on internal stores of calcium, i.e. bone and/or scales to increase calcium availability, the marine sea bream accommodates calcium-transporting mechanisms to obtain calcium from the environment and preserve internal stores. These observations suggest that a fundamental difference may exist in the $\mathrm{E}_{2}$-dependent calcium regulation between freshwater and marine teleosts.

Journal of Endocrinology (2002) 173, 377-385

\section{Introduction}

Calcium balance in fish has been extensively studied in freshwater species, mostly in salmonids and cichlids (for review see Flik et al. 1995). The majority of the calcium transport mechanisms are proposed to take place actively at the level of the gills (Flik et al. 1995) and, at least in some species, partly through the skin (McCormick et al. 1992, Marshall et al. 1992). In fresh water, fish drink very little and as a consequence virtually all the calcium incorporated via the intestine is of dietary origin. Thus, if dietary calcium is low, calcium requirements can be compensated by uptake via the gills from the surrounding medium (Ichii \& Mugiya 1983). Seawater fish, in contrast to freshwater fish, ingest large amounts of seawater to compensate for the osmotic water loss. Seawater contains around 10 mMolar calcium and thus drinking of seawater may provide a significant additional mode of calcium uptake. Although the contribution of the intestine to whole body calcium balance remains little studied in seawater species, there is some evidence that a varying proportion of the calcium imbibed may be absorbed by the intestine and this proportion may be species-specific (Schoenmakers et al. 1993, Sundell et al. 1993, Larsson et al. 1995).

Oestrogen treatment, administered usually in the form of oestradiol-17 $\beta\left(\mathrm{E}_{2}\right)$, is known to induce an increase in circulating levels of vitellogenin in fish (Bradley \& Grizzle 1989, Burzawa-Gerard \& Dumas-Vidal 1991, Mosconi et al. 1998), which is paralleled by an increase in blood plasma calcium (Persson et al. 1994, 1995, 1997). This increase in calcium demand during the reproductive period in freshwater fish is met not only from external sources but also by mobilisation of internal calcium stores, such as bone and scales which, in tilapia, account for up to $95 \%$ of the total body calcium (Flik et al. 1986). In goldfish, killifish (Mugiya \& Watabe 1977) and rainbow trout (Carragher \& Sumpter 1991, Persson et al. 1994, 1995, 1997), bone is initially spared and calcium mobilisation takes place predominantly from the scales. Moreover, in juvenile rainbow trout the effect of oestrogen at the level of the scales appears to be via high-affinity, low-capacity $\mathrm{E}_{2}$-binding sites (Persson et al. 2000) and 
oestrogen receptor mRNA is expressed in this tissue (Armour et al. 1997).

In the present study, the effect of $E_{2}$ on plasma calcium in a marine teleost, Sparus aurata, was investigated and the mechanism which increases internal calcium availability was also determined. The specific aims of the present study were: first, to establish the intestinal and extraintestinal contribution to whole body calcium uptake in seawater, secondly, to determine the changes in calcium metabolism in response to $\mathrm{E}_{2}$ and, thirdly, to evaluate the relative importance of internal and external calcium sources during periods of high demand such as vitellogenesis.

\section{Materials and Methods}

\section{Fish}

Immature sea bream (Sparus aurata) juveniles (1+ year old, body mass $31 \cdot 0 \pm 0.9 \mathrm{~g})$ were obtained from a stock raised from fertilised eggs at Ramalhete Marine Station (University of Algarve) and maintained under natural annual conditions of water temperature $\left(17-25^{\circ} \mathrm{C} ; 18^{\circ} \mathrm{C}\right.$ during the experiments), photoperiod and salinity (36$40 \%$; 37\%o during the experiments).

\section{$E_{2}$ treatment and sampling}

In April, juvenile sea bream $(n=60)$ were randomly distributed between two tanks and acclimated for 2 weeks prior to the start of the experiment. At the start of the experiment fish were anaesthetised with 2-phenoxyethanol (1:10 000 2-phenoxyethanol:seawater; Sigma-Aldrich, Madrid, Spain), one group $(n=30)$ received a peritoneal implant of coconut butter $(10 \mu \mathrm{l} / \mathrm{g}$ body weight; Sigma-Aldrich) containing $10 \mu \mathrm{g} / \mathrm{g}$ body weight $\mathrm{E}_{2}$ (Sigma-Aldrich) and the other group $(n=30)$ received the coconut butter alone (control). This $\mathrm{E}_{2}$ dose induces a chronic increase in the circulating levels of plasma $\mathrm{E}_{2}$ and vitellogenin in the sea bream and other teleosts (Persson et al. 1997, Mosconi et al. 1998). Control and $E_{2}$-treated fish were then distributed between two flow-through seawater tanks per treatment, each with 15 fish, and left undisturbed for 15 days. During this period, fish were fed daily at a rate of $2 \%$ of body weight/day on commercial sea bream pellets (Provimi, Faro, Portugal) between 1000 and $1100 \mathrm{~h}$, except that food was withheld $24 \mathrm{~h}$ prior to and on the day of the experiments and sampling. No deaths occurred during the experiment. At day 15, fish $(n=7)$ from both groups were sampled under anaesthesia (1:10 000 2-phenoxyethanol:seawater). Each fish was weighed to the nearest $0 \cdot 1 \mathrm{~g}$ and subsequently a $0.3 \mathrm{ml}$ blood sample was collected by puncture of the caudal vessels into heparinised (ammonium heparin, 30 units/ml; Sigma-Aldrich) $2 \mathrm{ml}$ syringes fitted with 25 guage needles. The puncture area was cleaned with tissue paper before blood was withdrawn to avoid contamination of the blood samples with seawater. Plasma was obtained by centrifugation of whole blood (10000 r.p.m. for $5 \mathrm{~min})$, aliquoted into four $(1.5 \mathrm{ml})$ vials, snap-frozen in liquid $\mathrm{N}_{2}$ and stored at $-80{ }^{\circ} \mathrm{C}$ for later analysis.

After collection of blood samples, fish were killed by decapitation and immediately blotted dry, the remaining mucus adhering to the scales was removed with a scalpel and the scales covering the lateral line collected, snapfrozen in liquid $\mathrm{N}_{2}$ and stored at $-80{ }^{\circ} \mathrm{C}$ for subsequent analysis. Livers were removed and weighed for calculation of the hepato-somatic index: HSI = (liver weight/body weight) $\times 100$.

\section{Whole body calcium uptake}

For determinations of whole body calcium uptake, control $(n=7)$ and $\mathrm{E}_{2}$-treated $(n=7)$ fish were transferred to individual seawater tanks ( 1.5 litres/fish $)$ set up with closed circuit water flow with aeration. Fish were left for $30 \mathrm{~min}$ and then $37 \mathrm{kBq} / 1{ }^{45} \mathrm{Ca}$ as ${ }^{45} \mathrm{CaCl}_{2}$ (specific activity $14.8 \mathrm{MBq} / \mu \mathrm{mol}$; NEN, Life Sciences Products, Boston, USA) and $37 \mathrm{kBq} / 1{ }^{51} \mathrm{Cr}$ as ${ }^{51} \mathrm{Cr}$-EDTA (specific activity $96.2 \mathrm{MBq} / \mu \mathrm{mol}$; NEN, Life Sciences Products) were added to the tank water and allowed to mix. The tanks were partially darkened with a black lid and fish were left to swim undisturbed. Exactly $2 \mathrm{~h}$ after the addition of the tracers, triplicate $2 \mathrm{ml}$ water samples were collected for counting and the radioactive solution was immediately replaced by tracer-free seawater. The fish were left to swim in this solution for 10 min to prevent any radioactivity from adhering to the body surfaces and then killed with an overdose of 2-phenoxyethanol (1:250 2-phenoxyethanol:seawater), blotted dry, quickly weighed to the nearest $0 \cdot 1 \mathrm{~g}$ and frozen at $-20{ }^{\circ} \mathrm{C}$. The whole frozen intestine, from oesophagus to rectum, from individual fish was subsequently dissected out. The intestine and carcass were then transferred separately to preweighed glass tubes and digested with nitric acid (1:10 of the sample weight) at $30{ }^{\circ} \mathrm{C}$ for 1 week. After digestion, samples were neutralised with equal volumes of $2 \mathrm{M}$ $\mathrm{NaOH}$, and a $2 \mathrm{ml}$ aliquot transferred to a scintillation counting vial. All samples, including tank water, digested intestines and carcasses were bleached with $2 \mathrm{ml} \mathrm{35 \%}$ hydrogen peroxide (Fluka; Sigma-Aldrich), to prevent colour quenching, incubated overnight at room temperature and then counted for 15 min in a Beckman LS6000IC scintillation counter after the addition of $20 \mathrm{ml}$ scintillation cocktail (OptiPhase HiSafe II, Wallac; Amersham Pharmacia Biotech). Total ${ }^{51} \mathrm{Cr}$ was measured in $2 \mathrm{ml}$ aliquots of tank water and in digested intestines by counting for $15 \mathrm{~min}$ in a Wallac 1470 Wizard gamma counter (Amersham Pharmacia Biotech).

Whole body calcium uptake (i.e. calcium influx) was calculated according to the following formula: $\mathrm{CI}=$ 
$($ Af $\times \mathrm{Cw}) /(\mathrm{Aw} \times t \times \mathrm{w})$, where Af is the total ${ }^{45} \mathrm{Ca}$ activity in the fish carcass (i.e. excluding the activity in the whole intestine which can be considered to be outside of the fish), Cw is the total calcium concentration in the water, Aw is total activity in the water, $t$ is duration of exposure $(\mathrm{h})$ and $\mathrm{w}$ is fish wet weight $(\mathrm{g})$. Whole body calcium influx rate is expressed as $\mathrm{nmol} / \mathrm{h}$ per $\mathrm{g}$. The total water calcium content was measured in triplicate (Sigma-Aldrich procedure no. 587).

\section{Intestinal calcium uptake}

The combination of whole body calcium influx and the amount of water imbibed (i.e. drinking rate) allows for estimation of the contribution of intestinal and extraintestinal uptake routes to whole body calcium uptake. Drinking rates (DR) were calculated as: $\mathrm{DR}=\mathrm{Af} /$ $($ Aw $\times t \times \mathrm{w})$, where Af is the total activity of ${ }^{51} \mathrm{Cr}$-EDTA in the intestine, Aw is the tracer concentration (c.p.m./ml) in water, $t$ is the duration of exposure (h) and $\mathrm{w}$ is fish wet weight $(\mathrm{g})$. Results are expressed as $\mu \mathrm{l} / \mathrm{h}$ per $\mathrm{g}$. Using the same expression for ${ }^{45} \mathrm{Ca}$, another estimate, the 'drinking rate', can be calculated. However, there is a crucial difference in the behaviour of the two tracers; while ${ }^{51} \mathrm{Cr}$-EDTA is not absorbed, ${ }^{45} \mathrm{Ca}$ crosses the intestinal wall. The difference in the estimated drinking rates using both tracers provides the amount of calcium imbibed which is actually absorbed by the intestine. The intestinal contribution to whole body calcium uptake $\left(\operatorname{Int}_{\mathrm{Ca}}\right)$ can be calculated as: $\mathrm{Int}_{\mathrm{Ca}}=\left(\mathrm{DR}_{\mathrm{Cr}}-\mathrm{Dr}_{\mathrm{Ca}}\right) \times \mathrm{W}_{\mathrm{Ca}}$, where $\mathrm{DR}_{\mathrm{Cr}}$ is the drinking rate calculated from ${ }^{51} \mathrm{Cr}$-EDTA values $(\mu \mathrm{l} / \mathrm{h}$ per $\mathrm{g}), \mathrm{DR}_{\mathrm{Ca}}$ is the drinking rate calculated from ${ }^{45} \mathrm{Ca}$ values ( $\mu \mathrm{l} / \mathrm{h}$ per $\left.\mathrm{g}\right)$ and $\mathrm{W}_{\mathrm{Ca}}$ is the water calcium concentration $(\mathrm{nmol} / \mu \mathrm{l})$. Results are expressed as $\mathrm{nmol} / \mathrm{g}$ per $\mathrm{h}$. The difference between $\mathrm{Int}_{\mathrm{Ca}}$ and the value for whole body calcium uptake estimates the contribution of the intestinal and extra-intestinal routes to the whole body calcium uptake.

\section{Whole body calcium efflux}

Control $(n=7)$ and $\mathrm{E}_{2}$-treated fish $(n=7)$ were loaded with ${ }^{45} \mathrm{Ca}$ by intraperitoneal injection of $37 \mathrm{kBq}{ }^{45} \mathrm{CaCl}_{2}$ dissolved in $500 \mu \mathrm{l} 0.9 \% \mathrm{NaCl}$ and transferred to separate tanks with flowing seawater for $48 \mathrm{~h}$ for recovery and to achieve a constant specific activity of the readily available calcium pool in the whole fish. Fish were then randomly and individually housed in 0.75 litre tanks and $1 \mathrm{ml}$ water samples were taken after $30 \mathrm{~min}$ and every $20 \mathrm{~min}$ thereafter for $2 \mathrm{~h}$. Fish were then killed by an overdose of anaesthetic (1:250 2-phenoxyethanol), weighed, a blood sample collected and plasma separated as described earlier. Both water and plasma samples were measured for ${ }^{45} \mathrm{Ca}$ radioactive decay as previously described. Calcium efflux rate $(\mathrm{ER})$ was calculated as follows: $\mathrm{ER}=(\mathrm{Aw} \times \mathrm{Ct}) /$ $($ At $\times t \times \mathrm{w})$, where Aw is the final specific activity in water, Ct is the total plasma calcium (mMol), At is the specific activity of ${ }^{45} \mathrm{Ca}$ in the plasma, $t$ is time (h) and $\mathrm{W}$ is fish wet weight $(\mathrm{g})$. Results are expressed as $\mathrm{nmol} / \mathrm{h}$ per $\mathrm{g}$.

$E_{2}$ assay

Individual plasma samples $(50 \mu \mathrm{l})$ were extracted twice with diethyl ether $\left(80 \% \mathrm{E}_{2}\right.$ recovery), resuspended in phosphate buffer containing $0.5 \mathrm{~g} / 1$ gelatine, $\mathrm{pH} 7 \cdot 6$ and radioimmunoassay was carried out with specific antibodies (Research Diagnostics, USA) following the general methods described by Scott et al. (1982). Crossreactivity of the antibody (expressed as \%) was as follows: 4-pregnene-3,20-dione $<0 \cdot 2 ; \quad 11 \beta, 17,21$-trihydroxy-4pregnene-3,20-dione $<0 \cdot 2 ; 4$-androstene-3,17-dione $<0 \cdot 2$; $17 \beta$-hydroxy-4-androsten-3-one $\quad<0 \cdot 2 ; \quad 3 \beta$-hydroxy5 -pregnen-20-one $\quad<0 \cdot 2 ; \quad 3 \beta$-hydroxy-5-androsten-17one $<0 \cdot 2$; 3-hydroxy-1,3,5(10)-estratrien-17-one $=15 ; 3$, $17 \beta$-dihydroxy-1,3,5(10)-estratrien-16-one $=8 ; 3,16 \alpha, 17 \beta$ trihydroxy-1,3,5(10)-estratrien-3-one $=0 \cdot 7 ; 3,16 \alpha$-dihydroxy$1,3,5(10)$-estratrien-17-one $<0 \cdot 2$. All samples were assayed in duplicate in a single assay. Inter- and intra-assay coefficients of variation determined were $8 \cdot 6 \%(n=3)$ and $4 \cdot 01 \%(n=5)$ respectively.

\section{Protein analysis}

Plasma protein Total plasma protein was measured in diluted samples $(1: 100)$ using the method of Lowry et al. (1951) with minor modifications for a micro plate reader (Benchmark; BioRad, Hercules, CA, USA). Bovine serum albumin (Sigma-Aldrich) was used as the standard. Results are given as $\mathrm{mg} / \mathrm{ml}$ plasma.

Vitellogenin Western blotting was used to confirm the identity of the plasma protein putatively designated as vitellogenin using a sea bream-specific vitellogenin polyclonal antibody. Diluted plasma $(12.5 \mu \mathrm{g}$ protein per sample) was mixed with an equal volume of sample buffer $(6 \%(\mathrm{w} / \mathrm{v})$ SDS, 6\% (v/v) 2-mercaptoethanol, 40\% (w/v) sucrose, $0.02 \%$ bromophenol blue in $0.125 \mathrm{M}$ Tris- $\mathrm{HCl}$, $\mathrm{pH}$ 6.8) boiled for $5 \mathrm{~min}$, spun (30 s, 12000 r.p.m.) and fractionated by SDS-PAGE according to Laemmli (1970). Molecular weight markers (Sigma-Aldrich) were run on all the gels to assist protein size identification. Gels were lightly stained with Coomassie blue $(0 \cdot 025 \%)$ and images captured with an image analysis system (Image Master VDS system; Amersham Pharmacia Biotech). Fractionated plasma proteins were transferred to a nitrocellulose membrane (NCP, Amersham Pharmacia Biotech) by electroblotting, using Tris-lysine ( $\mathrm{pH} \mathrm{8.2)}$ as the transfer buffer. Immunoblotting of membranes was carried out by blocking non-specific binding in MTw $(0 \cdot 1 \mathrm{M}$ Tris, $2 \%$ milk powder and $0.05 \%$ Tween 20) for $3 \mathrm{~h}$, rinsing in Tris $(0 \cdot 1 \mathrm{M})$, followed by incubation overnight at $4{ }^{\circ} \mathrm{C}$ with 
anti-sea bream vitellogenin serum (1:7000). Membranes were then washed with MTw and incubated with antirabbit IgG complexed with peroxidase (1:2000) for $1 \mathrm{~h}$ at room temperature with continuous agitation. After rinsing in Tris $(0 \cdot 1 \mathrm{M})$, membranes were developed using 4-chloro-1-napthol as the chromogen.

\section{Plasma calcium analysis}

Individual total plasma calcium (bound and free) and plasma calcium activity were measured in triplicate $(n=14$ controls; $n=14 \mathrm{E}_{2}$-implanted). Total plasma calcium was measured by colorimetric assay (Sigma-Aldrich procedure no. 587). Free calcium was measured by means of calcium-sensitive electrodes (MI-600; Microelectrodes Inc., Bedford, MD, USA) using an $\mathrm{Ag}-\mathrm{AgCl}$ electrode (MI-409; Microelectrodes Inc.) as an external reference. Plasma phosphorus was determined in triplicate in prediluted plasma using an endpoint colorimetric assay (Sigma-Aldrich procedure no. 360).

\section{Analysis of scales}

Calcium and phosphate scale content Frozen scales (20-30 mg) collected from individual fish were weighed, placed in glass tubes and digested with $1 \mathrm{ml}$ nitric acid for $24 \mathrm{~h}$ at $30^{\circ} \mathrm{C}$. The resulting digest was neutralised with equal volumes of $2 \mathrm{M} \mathrm{NaOH}$ and the volume in each tube increased to $5 \mathrm{ml}$ with double-deionised water. Total calcium and phosphate in the digests were measured in triplicate using the colorimetric methods described in the previous sections. Results are expressed as $\mu \mathrm{mol}$ calcium or phosphate/mg scale tissue.

Tartrate-resistant acid phosphatase (TRAP) To examine the changes in TRAP activity, 30-40 mg frozen scales from individual fish $(n=7$ per treatment) were homogenised at $4{ }^{\circ} \mathrm{C}$ using a glass-glass manual homogeniser in $1 \mathrm{ml}$ of a $0 \cdot 1 \mathrm{M}$ sodium acetate buffer $(\mathrm{pH} 5 \cdot 0)$. Homogenates were kept on ice and aliquots incubated in triplicate for $30 \mathrm{~min}$ at $22^{\circ} \mathrm{C}$, in acetate buffer $(0 \cdot 1 \mathrm{M}$, pH $5 \cdot 3)$ in the presence of $10 \mathrm{mM}$ para-nitrophenyl phosphate (Sigma-Aldrich) and $20 \mathrm{mM}$ tartrate. Para-nitro phenol (pNP; Sigma-Aldrich) was used as the standard. Enzyme activity measurements were performed according to the optimal assay conditions for TRAP measurements for fish scales (Persson et al. 1995) and shown to be similar to those reported for mammalian bone tissue (Lau et al. 1985).

\section{Statistics}

Values are shown as means \pm S.E.M. unless otherwise stated. Differences between groups were established by one-way analysis of variance (ANOVA) after assessing normality and homogeneity of variances. Groups were considered significantly different at $P<0 \cdot 05$.

\section{Results}

Effect of $E_{2}$ implants on plasma $E_{2}$, calcium and phosphate

Fifteen days after implantation, control sea bream had circulating plasma $\mathrm{E}_{2}$ levels of $0.49 \pm 0.18 \mathrm{ng} / \mathrm{ml}$ while in the $\mathrm{E}_{2}$-implanted group, levels had increased 14-fold to $7 \cdot 18 \pm 1 \cdot 89 \mathrm{ng} / \mathrm{ml}$ (Fig. 1A).

Total plasma calcium increased tenfold in response to $\mathrm{E}_{2}$ treatment, reaching $29.83 \pm 3.09 \mathrm{mmol} / 1$ compared with $2 \cdot 84 \pm 0.23 \mathrm{mmol} / \mathrm{l}$ in control fish. Levels of ionic calcium were $1.46 \pm 0.20 \mathrm{mmol} / 1$ in control fish $(51.4 \%$ of the total calcium) while, in $\mathrm{E}_{2}$-treated fish, ionic calcium was $3 \cdot 71 \pm 0.21 \mathrm{mmol} / \mathrm{l}$ (decreasing to only $12.4 \%$ of total). Despite the significant increase in both total and ionic calcium in the $E_{2}$-treated group compared with the control group, only a relatively small proportion of the calcium remained in an ionic form and the majority $(87.5 \%)$ was present in the protein-bound fraction of the total circulating calcium (Fig. 1B).

In parallel with increases in plasma calcium, $\mathrm{E}_{2}$ implants also caused a significant increase in plasma phosphate levels $(P<0 \cdot 01$, Fig. 1C) from $1.33 \pm 0.24 \mathrm{mmol} / 1$ in controls to $8.01 \pm 1.56 \mathrm{mmol} / \mathrm{l}$ in $\mathrm{E}_{2}$-treated fish.

\section{Drinking and intestinal calcium absorption}

The drinking rate measured by ${ }^{51} \mathrm{Cr}$-EDTA intake was unaffected by $\mathrm{E}_{2}$ treatment (Table 1 ) and was $5 \cdot 2-5 \cdot 3 \mu \mathrm{l} / \mathrm{h}$ per $\mathrm{g}$ in both groups. However, the estimates of drinking based on ${ }^{45} \mathrm{Ca}$ accumulation in the intestine were lower, ranging from 0.36 to $0.49 \mu \mathrm{l} / \mathrm{h}$ per $\mathrm{g}$. The difference between the two measurements was used to determine the proportion of calcium in the drinking water that was absorbed by the intestine, $89 \cdot 3 \pm 1 \cdot 4 \%$ for controls and $92 \cdot 8 \pm 0 \cdot 8 \%$ for $\mathrm{E}_{2}$-implanted fish (Table 1).

\section{Whole body calcium uptake}

Whole body calcium uptake increased significantly in response to $\mathrm{E}_{2}$ (Fig. 2A) from $64.1 \pm 1.8 \mathrm{nmol} / \mathrm{h}$ per $\mathrm{g}$ in control fish to $72.5 \pm 1.6 \mathrm{nmol} / \mathrm{h}$ per $\mathrm{g}$ in $\mathrm{E}_{2}$-implanted fish $(P<0 \cdot 01)$. The intestinal component of the whole body calcium uptake was $64 \cdot 9 \pm 2 \cdot 1 \%$ in the control group and $69 \cdot 5 \pm 3 \cdot 3 \%$ in the $\mathrm{E}_{2}$-implanted sea bream group (Fig. 2A).

\section{Calcium efflux and net calcium balance}

No differences in efflux were found between consecutive 20 -min periods in control $(P=0.837)$ or $\mathrm{E}_{2}$-treated 

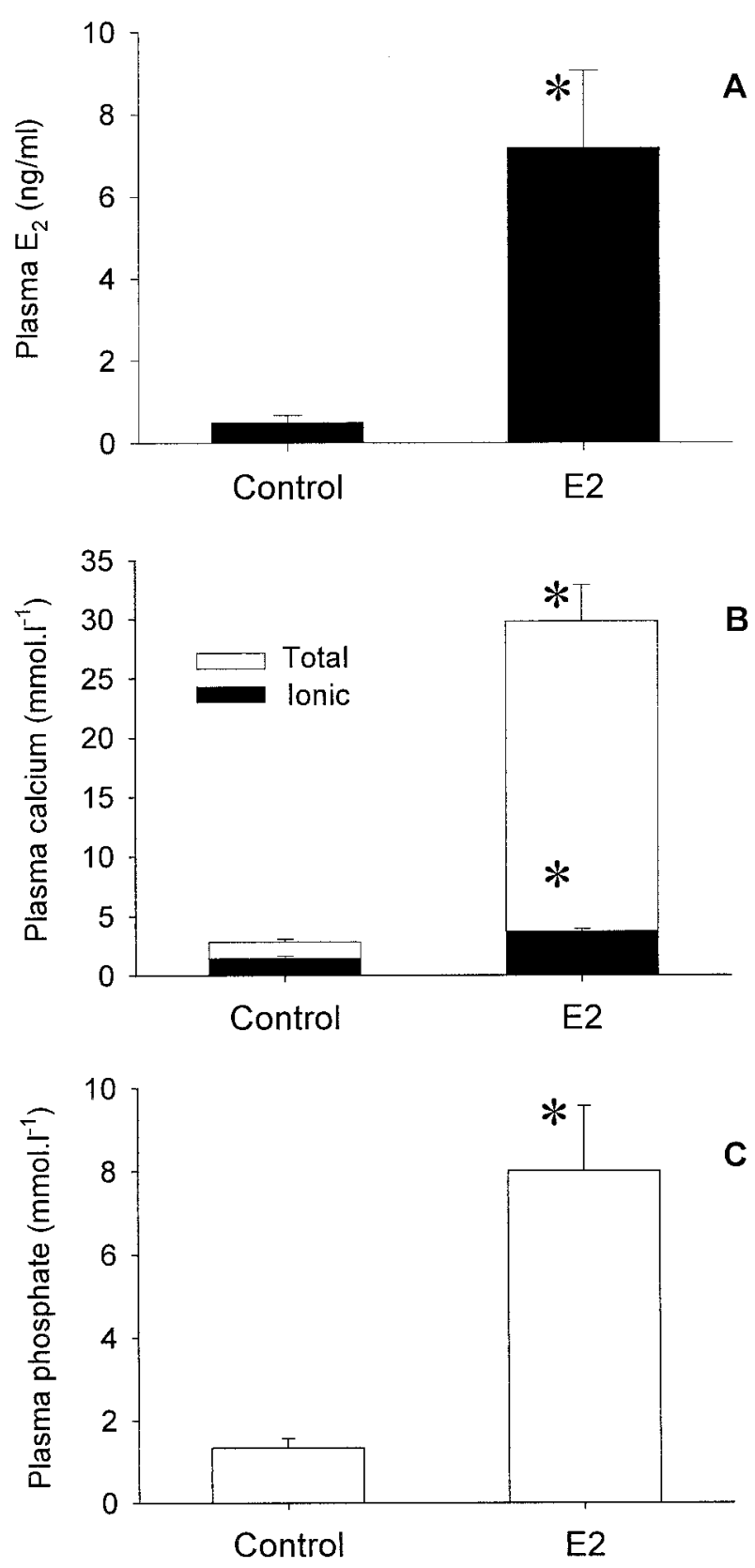

Figure 1 (A) Circulating plasma levels $(\mathrm{ng} / \mathrm{ml})$ of $E_{2}$ in sea bream juveniles 15 days after implantation of $10 \mu \mathrm{g} / \mathrm{g} \mathrm{E}_{2}$ in coconut butter implants $\left(E_{2}\right)$ or coconut butter alone (control). Each bar is the mean \pm S.E.M. of seven fish. ${ }^{*} P<0 \cdot 05$ (one-way ANOVA). (B) Total and ionic plasma calcium ( $\mathrm{mmol} / \mathrm{l})$ and (C) total plasma phosphate levels $(\mathrm{mmol} / \mathrm{l})$ in sea bream juveniles 15 days after treatment with $10 \mu \mathrm{g} / \mathrm{g} E_{2}$ in coconut butter implants $\left(E_{2}\right)$ or coconut butter implants alone (control). Values are given as means \pm S.E.M. of 14 fish per treatment. ${ }^{*} P<0 \cdot 001$ compared with corresponding controls (one-way ANOVA).
Table 1 Drinking rates based on ${ }^{51} \mathrm{Cr}$ uptake $\left(\mathrm{DR}_{\mathrm{Cr}}\right)$ and ${ }^{45} \mathrm{Ca}$ uptake $\left(D R_{C a}\right)$, the calculated percentage of absorbed calcium $\left(\%\right.$ absorbed), the intestinal calcium uptake $\left(\operatorname{Int}_{\mathrm{Ca}}\right)$ and the percentage contribution of intestinal calcium uptake to whole body calcium (\% intestinal calcium uptake) in sea bream juveniles 15 days after treatment with $10 \mu \mathrm{g} / \mathrm{g} \mathrm{E}_{2}$ in coconut butter implants $\left(E_{2}\right)$ or implants only (control). Values are the means \pm S.E.M. of $n=7$
$\mathrm{DR}_{\mathrm{Cr}}(\mu \mathrm{l} / \mathrm{h}$ per $\mathrm{g})$

$\mathrm{DR}_{\mathrm{Ca}}(\mu \mathrm{l} / \mathrm{h}$ per $\mathrm{g})$

$\%$ Absorbed

Int ${ }_{\mathrm{Ca}}(\mathrm{nmol} / \mathrm{h}$ per $\mathrm{g})$

$\%$ Intestinal calcium uptake

\begin{tabular}{|c|c|c|}
\hline Control & $E_{2}$ & $P$ value \\
\hline $5 \cdot 26 \pm 0 \cdot 74$ & $5 \cdot 27 \pm 0 \cdot 60$ & 0.961 \\
\hline $0 \cdot 49 \pm 0 \cdot 05$ & $0 \cdot 36 \pm 0.07$ & $0 \cdot 146$ \\
\hline $89 \cdot 3 \pm 1 \cdot 4$ & $92 \cdot 8 \pm 0 \cdot 8$ & 0.056 \\
\hline $41 \cdot 6 \pm 7 \cdot 9$ & $50 \cdot 4 \pm 5 \cdot 6$ & $0 \cdot 374$ \\
\hline $64 \cdot 9 \pm 2 \cdot 1$ & $69 \cdot 5 \pm 3 \cdot 3$ & $0 \cdot 360$ \\
\hline
\end{tabular}

$P$ values of one-way ANOVA are shown.
$(P=0.557)$ groups. Efflux data were therefore pooled for subsequent analysis and the average value of the $2-\mathrm{h}$ efflux period in each group is shown in Fig. 2B. Calcium efflux remained unchanged in response to $\mathrm{E}_{2}$ treatment. Both groups were in positive calcium balance, i.e. there was an average net uptake of calcium of $18.33 \mathrm{nmol} / \mathrm{h}$ per $\mathrm{g}$ in control and $24.03 \mathrm{nmol} / \mathrm{h}$ per $\mathrm{g}$ in $\mathrm{E}_{2}$-treated fish (Fig. 2C).

\section{Scale calcium, phosphate and TRAP}

The total calcium and phosphate content of the scales remained unaffected after 15 days of $\mathrm{E}_{2}$ treatment (Table 2). The calcium content of the scales in control fish was $1.25 \pm 0.07 \mu \mathrm{mol} / \mathrm{mg}$ vs $1.23 \pm 0.05 \mu \mathrm{mol} / \mathrm{mg}$ for $E_{2}$-treated fish, while phosphate scale content was $0.96 \pm 0.07 \mu \mathrm{mol} / \mathrm{mg}$ in controls and $1.00 \pm 0.05 \mu \mathrm{mol} /$ $\mathrm{mg}$ in $\mathrm{E}_{2}$-treated fish (Table 2). Furthermore, TRAP activity, a marker of osteoclastic activity, in the scales was not altered by $\mathrm{E}_{2}$ treatment (Table 2).

\section{Plasma protein analysis}

Circulating levels of plasma protein were increased nearly threefold in response to $\mathrm{E}_{2}$ treatment $(28 \cdot 3 \pm$ $6.2 \mathrm{mg} / \mathrm{ml}$ plasma vs $95.2 \pm 13.0 \mathrm{mg} / \mathrm{ml}$ plasma, $P<0 \cdot 001)$. SDS-PAGE and Western blot analysis of plasma protein confirmed that $\mathrm{E}_{2}$ treatment induced a significant increase in circulating levels of vitellogenin; the latter protein was undetectable in the plasma of control fish. Associated with the increased vitellogenin production by the liver was a significant increase in the HSI of $E_{2}$-treated fish compared with the control group, $3 \cdot 3 \pm 0 \cdot 4 \%$ plasma vs $2 \cdot 27 \pm 0 \cdot 2 \%$ plasma $(P<0 \cdot 05)$ respectively.

\section{Discussion}

In the present study, the increase in circulating levels of $\mathrm{E}_{2}$ in response to $\mathrm{E}_{2}$ treatment was associated with 

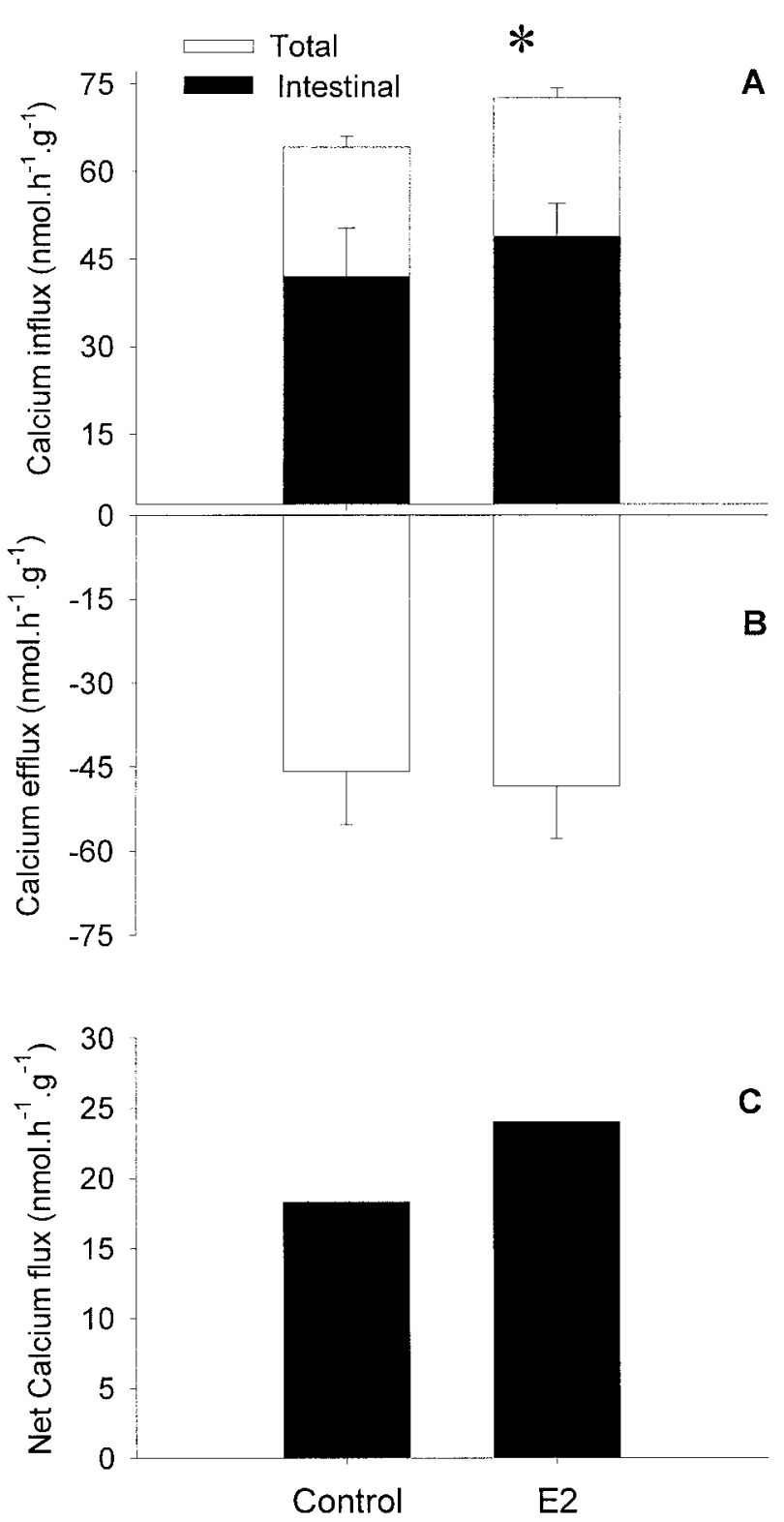

Figure 2 Whole body (A) calcium uptake, (B) calcium efflux and (C) net calcium flux in sea bream juveniles 15 days after treatment with $10 \mu \mathrm{g} / \mathrm{g} E_{2}$ in coconut butter implants $\left(E_{2}\right)$ or coconut butter implants alone (control). Each bar represents the mean \pm S.E.M. of seven fish. ${ }^{*} P<0 \cdot 001$ compared with corresponding controls (one-way ANOVA).

significantly elevated plasma levels of both protein bound and ionic calcium. The experimental evidence indicated that there are at least two major components involved in the elevation of plasma calcium levels: an increase in calcium uptake from the water and an increase in intestinal calcium absorption. Thus, in the sea bream, $\mathrm{E}_{2}$ appears to participate directly or indirectly in the regulation of these components.
Table 2 Calcium, phosphate and TRAP activity (means \pm S.E.M., $n=7$ ) in the scales of sea bream juveniles 15 days after treatment with $10 \mu \mathrm{g} / \mathrm{g} \mathrm{E}_{2}$ in coconut butter implants $\left(E_{2}\right)$ or implants only (control)

\begin{tabular}{|c|c|c|c|}
\hline & Control & $E_{2}$ & $P$ value \\
\hline Calcium ( $\mu \mathrm{mol} / \mathrm{mg}$ ) & $1 \cdot 26 \pm 0 \cdot 07$ & $1 \cdot 24 \pm 0 \cdot 05$ & $0 \cdot 838$ \\
\hline Phosphate $(\mu \mathrm{mol} / \mathrm{mg})$ & $0.96 \pm 0.07$ & $1 \cdot 00 \pm 0 \cdot 05$ & $0 \cdot 697$ \\
\hline TRAP $(\mu \mathrm{mol} p \mathrm{NP} / \mathrm{h}$ per mg) & $11 \cdot 9 \pm 1 \cdot 2$ & $14 \cdot 9 \pm 1 \cdot 9$ & $0 \cdot 235$ \\
\hline
\end{tabular}

Calcium exchange in fish takes place mostly at the level of the gills, with contributions from the skin (i.e. opercular membrane; McCormick et al. 1992, Marshall et al. 1992) and from the diet via the intestine. In the present study, we aimed to determine the contribution of the intestine to calcium regulation since marine fish drink large amounts of seawater (containing $10 \mathrm{mmol} / \mathrm{l}$ calcium in our experiments) and the intestine is known to play an important role in osmoregulation. Previous studies have shown that the proportion of the calcium taken up from water in the intestine of seawater fish is very variable. For example, the cod (Gadus morhua) absorbs about 30\% of the calcium from drinking water (Sundell et al. 1993), while the flounder (Paralichthys lethostigma) absorbs about 70\% (Hickman 1968). In tilapia (Oreochromis mossambicus), it has been shown that the net calcium transport in the intestine of seawater-adapted fish is significantly lower than in their freshwater counterparts, in which the uptake of calcium by the intestine represents a high proportion of whole body calcium uptake (Schoenmakers et al. 1993). In the present study, when the various routes of calcium entry into the body are considered, the high absorption rate in the intestine of sea bream translates into an intestinal component of the whole body calcium uptake in the range of $60-70 \%$ (Table 1). Moreover, since the branchial component of calcium uptake is in negative balance, it is the intestinal route that compensates for the calcium loss and maintains the fish in a positive calcium balance (Fig. 2).

The drinking rate of control and $\mathrm{E}_{2}$-treated fish was the same $(5 \cdot 2 \mu \mathrm{l} / \mathrm{h}$ per $\mathrm{g})$ and is similar to that previously observed in other marine species (Fuentes \& Eddy 1997). However, one of the effects of $E_{2}$ treatment appears to be an increase in the relative proportion of the calcium taken up as drinking water that is absorbed (Table 1). An increase of calcium uptake at the intestinal level, $89 \%$ in controls versus $93 \%$ in the $\mathrm{E}_{2}$-treated fish (Fig. 2A), coupled with an unchanged rate of calcium efflux (Fig. $2 \mathrm{~B})$ results in a $31 \%$ increase of the net whole body calcium uptake (Fig. 2C). However, this 31\% increase cannot account for the final plasma calcium differences found between control and $E_{2}$-treated fish at the end of the experiment. Intriguingly, when plasma ionic calcium 
(the physiologically important fraction) instead of total calcium is used to estimate calcium efflux rates, a threefold reduction was observed in $\mathrm{E}_{2}$-treated animals, which results in a nearly $40 \%$ calculated increment in the net influx. This change would be sufficient to explain the increase in total (and free) plasma calcium in the $\mathrm{E}_{2^{-}}$ treated group, assuming that the $\mathrm{E}_{2}$ starts to have an effect soon after implantation.

In the $E_{2}$-treated sea bream, vitellogenin was very abundant in plasma but was not detected in control fish. It was not determined whether the tenfold increase in plasma calcium in the $\mathrm{E}_{2}$-treated fish was exclusively associated with higher levels of circulating vitellogenin or whether there may have been additional calcium-binding proteins in the plasma. However, previous reports suggest that virtually all of the calcium in oestrogen-treated freshwater trout is bound to vitellogenin (Persson et al. 1994, 1995).

That the source of plasma calcium appears to be mainly the environment was supported by the fact that the phosphate and calcium content of the scales in $\mathrm{E}_{2^{-}}$ implanted juveniles remained unchanged, while the plasma calcium levels were increased to a level higher than those described in salmonids (Persson et al. 1997). This is in marked contrast to studies with rainbow trout in which considerable mobilisation of calcium from the scales was reported (Persson et al. 1997). The lack of calcium mobilisation from the scales in sea bream was further confirmed by the absence of $\mathrm{E}_{2}$-stimulated TRAP activity (Table 2) and contrasts with the effects of $E_{2}$ seen in rainbow trout (Persson et al. 1994, 1997). In salmonids, it has been suggested that increased calcium demand responds to a need for bone remodelling during reproductive riverine upstream migration. This increased calcium demand for bone remodelling is obtained not only from the environment but also from internal stores. The hypothesis of a direct effect of oestrogen on bone and/or scale remodelling in salmonids is supported by detection of oestrogen receptor $\alpha(E R \alpha)$ mRNA expression in these tissues in the trout (Armour et al. 1997). Also, Persson et al. (2000) recently characterised a high-affinity, low-capacity binding of $\mathrm{E}_{2}$ to trout scales. In the sea bream, ER $\alpha$ mRNA is not detected in bone and $\operatorname{ER} \beta$ is expressed at low levels (only detectable by RT-PCR; Socorro et al. 2000). The expression of ER in sea bream scales has yet to be determined, but the failure of $\mathrm{E}_{2}$ to stimulate calcium mobilisation from scales in the sea bream suggests that the receptor is probably absent.

Whether the effect of oestradiol on calcium transport mechanisms in the sea bream occurs by a direct action on the gills, intestine and/or kidney, or is mediated by its action via the hypothalamic-pituitary axis and/or other endocrine systems, remains to be established. However, it has recently been shown (Socorro et al. 2000) that neither $\mathrm{ER} \alpha$ nor ER $\beta$ are expressed by the gills of sea bream, making it unlikely that oestradiol has a direct effect on calcium transport via ER in this tissue but mediates its effects, if any, via a calcitropic factor. In contrast, there is high expression of ER $\beta$ in the sea bream intestine and kidney (Socorro et al. 2000). The increase in net calcium influx (Fig. 2C) in response to $E_{2}$ in sea bream may be explained, at least in part, by a direct action via ER $\beta$ in these tissues. In some tetrapods, a similar effect of $E_{2}$ on the intestine and kidney, which can be blocked by oestrogen antagonists (e.g. Nordin et al. 1991, ten Bolscher et al. 1999), has been observed.

Teleosts possess two hormones with hypocalcaemic action, but so far no hypercalcaemic factor has been identified. The hypocalcaemic factors include stanniocalcin which was originally isolated, characterised and its biological activity determined in fish (for review see Wendelaar Bonga \& Pang 1991, Wagner et al. 1998) and calcitonin which has hypocalcaemic effects in goldfish (Sasayama et al. 1993) and salmonids (Wagner et al. 1997). The principal hypercalcaemic factor identified in tetrapods, parathyroid hormone (PTH), has not been identified in fish. However, both puffer fish (Power et al. 2000) and the sea bream (Flanagan et al. 2000) have recently been shown to express the gene for PTH-related protein (PTHrP), and a peptide corresponding to the amino acid residues $1-38$ of the $\mathrm{N}$-terminal region of $\mathrm{PTHrP}$ was able to cause an elevation in whole body calcium uptake in sea bream larvae, by increasing uptake and decreasing efflux of calcium (Guerreiro et al. 2001). Although the involvement of PTHrP in the hypercalcaemic effect of $\mathrm{E}_{2}$ in the present study was beyond the experimental objectives, there is supporting evidence from mammalian studies that $\mathrm{E}_{2}$ increases renal expression of PTHrP mRNA without modifying PTH/PTHrP receptor level of expression (Cros et al. 1998), thus preventing the renal leak of calcium in osteoporotic women (Nordin et al. 1991, Cros et al. 1998).

In fish, several other candidate hypercalcaemic hormones have been identified and include prolactin (Flik et al. 1994), cortisol and growth hormone (Flik \& Perry 1989, Takagi et al. 1992). The link between calcium balance, oestrogen and pituitary hormone expression, i.e. prolactin, growth hormone and somatolactin in sea bream, is currently under study and preliminary results show a down-regulation of pituitary gene expression of these hormones in response to $E_{2}(J$ Fuentes, unpublished observations). However, the relative importance of calcium and $E_{2}$ on this effect has yet to be established.

In conclusion, our data suggest that the sea bream, in common with freshwater teleosts, respond to increases in circulating $\mathrm{E}_{2}$ with an increase in circulating plasma levels of vitellogenin, total calcium and an accommodation of the calcium-transporting mechanisms. However, the source of calcium and mechanisms by which internal circulating levels are increased appear to be different between freshwater and marine teleosts. While freshwater fish may rely on the internal stores of calcium, i.e. bone and/or scales to increase calcium availability, the sea bream, a marine fish, fulfils the extra calcium demand by utilising the high 
environmental calcium and, by doing so, protects internal calcified structures. It remains to be seen if the profound effects of $E_{2}$ on calcium balance in sea bream are direct, or are mediated by other endocrine factors.

\section{Acknowledgements}

This study was funded by the project PRAXIS/P/BIA/ 13174/98. P M G and J F were funded by the Ministry of Science, FCT, Portugal, through grants BD/9207/96 and BPD/22033/99 respectively. We thank Dr Patricia M Ingleton for helpful discussions during the study and for reading and commenting on the manuscript.

\section{References}

Armour KJ, Lehane DB, Pakdel F, Valotaire Y, Graham R, Russell RG \& Henderson IW 1997 Estrogen receptor mRNA in mineralized tissues of rainbow trout: calcium mobilization by estrogen. FEBS Letters 411 145-148.

ten Bolscher M, Netelenbos JC, Barto R, Van Buuren LM \& Van der Vijgh WJF 1999 Estrogen regulation of intestinal calcium absorption in the intact and ovariectomized adult rat. Journal of Bone and Mineral Research 14 1197-1202.

Bradley JT \& Grizzle JM 1989 Vitellogenin induction by estradiol in channel catfish, Ictalurus punctatus. General and Comparative Endocrinology 73 28-39.

Burzawa-Gerard E \& Dumas-Vidal A 1991 Effects of $17 \beta$-estradiol and carp gonadotropin on vitellogenesis in normal and hypophysectomized European silver female eel (Anguilla anguilla L.) employing a homologous radioimmunoassay for vitellogenin. General and Comparative Endocrinology 84 264-276.

Carragher JF \& Sumpter JP 1991 The mobilization of calcium from calcified tissues of rainbow trout (Oncorhynchus mykiss) induced to synthesize vitellogenin. Comparative Biochemistry and Physiology 99A 169-172.

Cros M, Silve C, Graulet AM, Morieux C, Urena P, de Vernejoul MC \& Bouizar 1998 Estrogen stimulates PTHrP but not PTH/ $\mathrm{PTHrP}$ receptor gene expression in the kidney of ovariectomized rat. Journal of Cellular Biochemistry 70 84-93.

Flanagan JA, Power DM, Bendell LA, Guerreiro PM, Fuentes J, Clark MS, Canario AVM, Danks JA, Brown BL \& Ingleton PM 2000 Cloning of the cDNA for sea bream (Sparus aurata) parathyroid hormone-related protein. General and Comparative Endocrinology 118 373-382.

Flik G \& Perry SF 1989 Cortisol stimulates whole body calcium uptake and the branchial calcium pump in freshwater rainbow trout. Journal of Endocrinology 120 75-82.

Flik G, Fenwick JC, Kolar Z, Mayer-Gostan N \& Wendelaar Bonga SE 1986 Effects of low ambient calcium levels on $\mathrm{Ca}^{2+}$ flux rates and internal calcium pools in the freshwater cichlid teleost, Oreochromis mossambicus. Journal of Experimental Biology 120 249-264.

Flik G, Rentier-Delrue F \& Wendelaar Bonga SE 1994 Calcitropic effects of recombinant prolactins in Oreochromis mossambicus. American Journal of Physiology 266 R1302-R1308.

Flik G, Verbost PM \& Wendelaar Bonga SE 1995 Calcium transport processes in fishes. In Fish Physiology, vol. 14: Cellular and Molecular Approaches to Fish Ionic Regulation, pp 317-342. Eds CM Wood \& T Shuttleworth. San Diego: Academic Press.

Fuentes J \& Eddy FB 1997 Drinking in freshwater, euryhaline and marine teleosts. In Ionic Regulation in Animals, pp 135-149. Eds N Hazon, FB Eddy \& G Flik. Berlin, Heidelberg: Springer-Verlag.
Guerreiro PM, Fuentes J, Power DM, Ingleton PM, Flik G \& Canario AVM 2001 Parathyroid hormone-related protein: a calcium regulatory factor in sea bream (Sparus aurata L.) larvae. American Journal of Physiology 281 R855-R860.

Hickman CPJ 1968 Ingestion, intestinal absorption and elimination of sea water and salts in the southern flounder, Paralichthys lethostigma. Canadian Journal of Zoology 46 457-466.

Ichii T \& Mugiya Y 1983 Effects of dietary deficiency in calcium on growth and calcium uptake from the aquatic environment in the goldfish, Carassius auratus. Comparative Biochemistry and Physiology 74A 259-262.

Laemmli UK 1970 Cleavage of structural proteins during the assembly of the head of bacteriophage T4. Nature 227 680-685.

Larsson D, Bjornsson BT \& Sundell K 1995 Physiological concentrations of 24,25-dihydroxyvitamin D3 rapidly decrease the in vitro intestinal calcium uptake in the Atlantic cod, Gadus morhua. General and Comparative Endocrinology 100 211-217.

Lau K-WH, Farley JR \& Baylink DJ 1985 Phosphotyrosyl-specific protein phosphatase activity of a bovine skeletal acid phosphatase isoenzyme. Journal of Biological Chemistry 260 4653-4660.

Lowry OH, Rosebrough NJ, Farr AL \& Randall RJ 1951 Protein measurement with the folin-phenol reagents. Journal of Biological Chemistry 193 265-275.

McCormick SD, Hasegawa S \& Hirano T 1992 Calcium uptake in the skin of a freshwater teleost. PNAS 89 3635-3638.

Marshall WS, Bryson SE \& Wood CM 1992 Calcium transport by isolated skin of rainbow trout. Journal of Experimental Biology 166 297-316.

Mosconi G, Carnevali O, Carletta R, Nabissi M \& Polzonetti-Magni AM 1998 Gilthead sea bream (Sparus aurata) vitellogenin: purification, partial characterization, and validation of an enzyme-linked immunosorbent assay (ELISA). General and Comparative Endocrinology 110 252-261.

Mugiya Y \& Watabe N 1977 Studies on fish scale formation and resorption. II. Effect of estradiol on calcium homeostasis and skeletal tissue in the goldfish, Carassius auratus and the killifish, Fundulus heteroclitus. Comparative Biochemistry and Physiology 57A 197-202.

Nordin BEC, Need AG, Morris HA, Horowitz M \& Robertson WG 1991 Evidence for a renal calcium leak in postmenopausal women. Journal of Clinical Endocrinology and Metabolism 72 401-407.

Persson P, Sundell K \& Björnsson BT 1994 Estradiol-17 $\beta$ induced calcium uptake and resorption in juvenile rainbow trout, Oncorhynchus mykiss. Fish Physiology and Biochemistry 13 379-386.

Persson P, Takagi Y \& Björnsson BT 1995 Tartrate resistant acid phosphatase as a marker for scale resorption in rainbow trout, Oncorhynchus mykiss: effects of estradiol-17 $\beta$ treatment and refeeding. Fish Physiology and Biochemistry 14 329-339.

Persson P, Johannsson SH, Takagi Y \& Björnsson BT 1997 Estradiol-17 $\beta$ and nutritional status affect calcium balance, scale and bone resorption, and bone formation in rainbow trout, Oncorhynchus mykiss. Journal of Comparative Physiology B 167 468-473.

Persson P, Shrimpton JM, McCormick SD \& Björnsson BT 2000 The presence of high-affinity, low-capacity estradiol-17 $\beta$ binding in rainbow trout scale indicates a possible route for the regulation of scale resorption. General and Comparative Endocrinology 120 35-43.

Power DM, Ingleton PM, Flanagan J, Canario AVM, Danks JA, Elgar G \& Clark MS 2000 Genomic structure and expression of parathyroid hormone-related protein gene (PTHrP) in a teleost, Fugu rubripes. Gene 250 67-76.

Sasayama Y, Ukawa K, Kai-Ya H, Oguro C, Takei Y, Watanabe TX, Nakajima K \& Sakakibara S 1993 Goldfish calcitonin: purification, characterization, and hypocalcemic potency. General and Comparative Endocrinology 89 189-194.

Schoenmakers TJM, Verbost PM, Flik G \& Wendelaar Bonga SE 1993 Transcellular intestinal calcium transport in freshwater and seawater fish and its dependence on sodium/calcium exchange. Journal of Experimental Biology 176 195-206. 
Scott AP, Sheldrick EL \& Flint APF 1982 Measurement of 17 alpha, 20 beta-dihydroxy-4-pregnen-3-one in plasma of trout (Salmo gairdneri Richardson): seasonal changes and response to salmon pituitary extract. General and Comparative Endocrinology 46 444-451.

Socorro S, Power DM, Olsson P-E \& Canario AVM 2000 Two estrogen receptors expressed in the teleost fish, Sparus aurata: cDNA cloning, characterization and tissue distribution. Journal of Endocrinology 166 293-306.

Sundell K, Norman AW \& Björnsson BT 1993 1,25(OH $)_{2}$ vitamin D3 increases ionized plasma calcium concentrations in the immature Atlantic cod, Gadus morhua. General and Comparative Endocrinology 91 344-351.

Takagi Y, Moriyama S, Hirano T \& Yamada J 1992 Effects of growth hormones on bone formation and resorption in rainbow trout (Oncorhynchus mykiss), as examined by histomorphometry of the pharyngeal bone. General and Comparative Endocrinology 86 90-95.

Wagner GF, Jaworski EM \& Radman DP 1997 Salmon calcitonin inhibits whole body $\mathrm{Ca}^{2+}$ uptake in young rainbow trout. Journal of Endocrinology 155 459-465.

Wagner GF, Jaworski EM \& Haddad M 1998 Stanniocalcin in the seawater salmon: structure, function, and regulation. American Journal of Physiology 274 R1177-R1185.

Wendelaar Bonga SE \& Pang PKT 1991 Control of calcium regulating hormones in the vetebrates: parathyroid hormone, calcitonin, prolactin and stanniocalcin. International Review of Cytology 128 139-213.

Received in final form 2 January 2002

Accepted 22 January 2002 